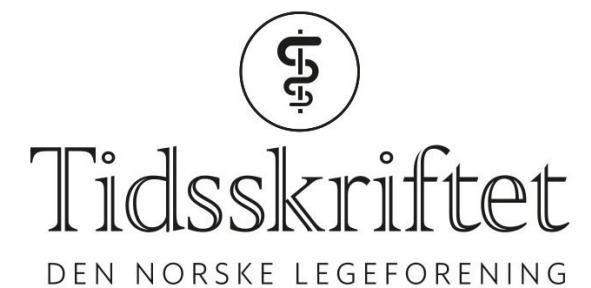

DEN NORSKE LEGEFORENING

\title{
Amming som globalt folkehelsetiltak
}

FRA REDAKTØREN

MARTINE ROSTADMO

E-post: martine.rostadmo@tidsskriftet.no

Martine Rostadmo (f. 1980) er lege og medisinsk redaktør i Tidsskriftet.

Amming er nært, intimt og privat, men det er også folkehelse. Mer enn 800 ooo barnedødsfall kunne vært forhindret årlig om mødre i lavinntektsland hadde ammet $\mathrm{i}$ stedet for å bruke morsmelkerstatning.

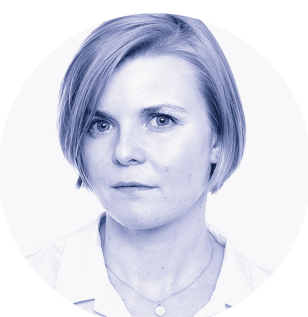

Foto: Sturlason

«Bryst er best». Det har vi visst lenge, men aldri før har vi visst så mye om hvorfor. Morsmelk beskytter mot diaré, luftveisinfeksjoner og mellomørebetennelse. I land med høy barnedødelighet ville beskyttelse mot disse sykdommene kunne spart 823 ooo barneliv årlig om $90 \%$ av mødre ammet (1). Amming ser også ut til å gi en liten økning i IQ, beskjeden på individnivå, men på befolkningsnivå en uutnyttet ressurs (2).

Morsmelk er persontilpasset medisin - melken påvirker genekspresjon på måter vi tidligere ikke har vært klar over $(1,3)$. Morsmelken preger også spedbarnets mikrobiom, blant annet gjennom sukkerarter som ikke tas opp, men som stimulerer til vekst av gunstige tarmbakterier (4). Via den nylig oppdagede entero-mammariske rute tas også mors levende tarmbakterier opp av dendrittiske celler i mors tarm før de skilles ut i melken og dermed blir en del av barnets mikrobiom (5). Hvordan morsmelk påvirker sykdom og helse gjennom mikrobiomet, kan vi vente å høre mer om i kommende år.

Også for mor gir amming helsegevinst: Omkring 20 ooo dødsfall per år som følge av brystkreft kunne vært unngått blant mødre i lavinntektsland om flere hadde ammet. I tillegg beskytter amming mot eggstokkreft og diabetes (1).

For klima og miljø er melk fra mors bryst et nær perfekt alternativ. Produksjon av morsmelkerstatning er ressurskrevende. Både kuer, fabrikker og transport over lange avstander gir utslipp av klimagasser. Det kreves $4000 \mathrm{l}$ vann for å fremstille $1 \mathrm{~kg}$ pulver (2). Hos forbruker kreves rent vann som ofte kommer langveisfra på flaske, og tilberedning og sterilisering av flaskene krever energi. Plastemballasjen og tåteflaskene ender til slutt på søppeldynga. Det babyen ikke drikker opp, har kort holdbarhet og må ofte kastes. Dette i 
motsetning til amming, som krever svært sparsomt med ressurser (et par brødskiver, litt frukt og 1-2 l vann per døgn), ingen emballasje, ingen transport, ingen plastikk, intet svinn.

I lavinntektsland er morsmelkerstatning et utrygt alternativ. Ikke alle har tilgang til rent vann og en varmekilde for koking og sterilisering. I tillegg bør man kunne lese for å forstå blandingsforholdet. Har man først sluttet å amme, må man være sikker på at man har penger til å kjøpe pulver hele spedbarnsperioden. Mødre som gir spedbarnet sitt flaske, er sårbare i kriser og katastrofer. I Jemen er ammetallene lave, og under borgerkrigen har spedbarn rett og slett sultet i hjel fordi mødrene ikke ammer, og fordi det ikke har vært stabil tilgang til morsmelkerstatning $(6,7)$.

I 1970-årene ble Nestlé boikottet på grunn av uetisk markedsføring av morsmelkerstatning i fattige land. Det resulterte blant annet i at Verdens helseorganisasjon lagde en kodeks for hvordan markedsføring av morsmelkerstatning skulle foregå. I den står at morsmelkerstatning ikke skal markedsføres som et bedre alternativ enn amming, og at det ikke skal deles ut gratis prøver (8). Likevel skjer dette i stor stil i lavinntektsland.

Helsepersonell får penger fra produsentene for å dele ut vareprøver til gravide.

Produsentene lover at deres produkt skal gjøre barnet smartere. Er man en lojal kunde, får man kanskje ellers uoppnåelige goder, som en trehjulssykkel. Men det koster. I en rapport fra Redd Barna kan man lese om kvinner som selv sulter eller ikke har mat til de eldre barna, fordi pengene går til morsmelkerstatning (8).

Produsentene av morsmelkerstatning tjener gode penger. Salget har femdoblet seg de siste 20 årene, vesentlig mer enn det befolkningsveksten skulle tilsi (8). Oljefondet er den nest største investoren i Nestlé, og Redd Barna legger nå press på dem for at de skal utøve mer aktivt eierskap og stoppe den uetiske markedsføringen av morsmelkerstatning. Det er et skritt i riktig retning.

Når amming har så åpenbare helsemessige konsekvenser, bør det være et høyt prioritert folkehelsetiltak å spre informasjon om dette i hele verden. Når temaet likevel ikke får særlig mye oppmerksomhet, kan det kanskje skyldes at amming tilhører «kvinnesfæren», med tilhørende lav status og prioritet.

En del av det å være mor er å ville gi barnet sitt det man mener er det aller beste. Mødre i Norge holder ut blødende brystvorter og det som verre er for å få til ammingen, og må de gi opp, er det ofte sårt. Mødre i lavinntektsland sulter for å få råd til morsmelkerstatning. Vi kan ikke godta at en kynisk industri fratar sårbare mødre muligheten til å ta et informert valg om hva som er best for seg og sitt barn.

\section{LITTERATUR:}

1. Victora CG, Bahl R, Barros AJ et al. Breastfeeding in the 21st century: epidemiology, mechanisms, and lifelong effect. Lancet 2016; 387: 475 - 90. [PubMed][CrossRef]

2. Rollins NC, Bhandari N, Hajeebhoy N et al. Why invest, and what it will take to improve breastfeeding practices? Lancet 2016;387: 491 - 504. [PubMed][CrossRef]

3. Verduci E, Banderali G, Barberi S et al. Epigenetic effects of human breast milk. Nutrients 2014; 6:1711 - 24. [PubMed][CrossRef]

4. Le Doare K, Holder B, Bassett A et al. Mother's milk: a purposeful contribution to the development of the infant microbiota and immunity. Front Immunol 2018; 9:361. [PubMed][CrossRef]

5. Rodríguez JM. The origin of human milk bacteria: is there a bacterial entero-mammary pathway during late pregnancy and lactation? Adv Nutr 2014; 5: 779 - 84. [PubMed][CrossRef]

6. Tjelle I. Udai (5 mnd.) døde av sult i jemen.

https://www.nrk.no/urix/sma-barn-dor-av-sult-i-borgerkrigsherjede-jemen-1.12874557 (9.5.2018).

7. Sarhan J. Yemen's breastfeeding challenge.

https://www.aljazeera.com/news/middleeast/2014/o6/yemen-breastfeeding-challenge-201462212225988 6759.html (9.5.2018). 
8. Macon F, Greer H. Don't push it: Why the formula milk industry must clean up its act. Report 2018. https://www.savethechildren.org.uk/content/dam/gb/reports/health/dont-push-it.pdf? (9.5.2018).

Publisert: 28. mai 2018. Tidsskr Nor Legeforen. DOI:10.4045/tidsskr.18.0432

(C) Tidsskrift for Den norske legeforening 2020. Lastet ned fra tidsskriftet.no 